\title{
Effect of tray drying on the moisture kinetic and drying rate of osmo-dried papaya slices
}

\author{
Vikrant Kumar*, Jaivir Singh, Suresh Chandra, Neelash Chauhan, Ratnesh Kumar, Sunil \\ and Vipul Chaudhary
}

Department of Agricultural Engineering, SVPUAT, Meerut (UP)

*Email:vkvk6096@gmail.com

\begin{abstract}
The experiment was conducted to determine the drying rate, drying time, moisture content of osmotically papaya samples. Drying of papaya samples in a tray dryer takes only 540 minutes for drying from an initial moisture content of $89 \%(\mathrm{wb})$ to a final moisture content of $2.4,5.3$ and $1.7 \%(\mathrm{db})$ of $55^{\circ} \mathrm{Brix}$ and the final moisture content were recorded of $65^{\circ}$ Brix that $3.66,3.12$ and $5.9 \%(\mathrm{db})$ for $\mathrm{T}_{1}, \mathrm{~T}_{2}$ and $\mathrm{T}_{3}$ samples. The drying temperature is the main factor controlling the rate of drying. It is an important parameter for internal water transfer in the product.
\end{abstract}

Keywords: Tray Dryer, Osmo-dried Papaya Slices, Moisture Content, Drying Rate, Drying Time.

Paper Cited: Kumar, V., Singh, J., Chandra, S., Chauhan, N., Kumar, R., Sunil and Chaudhary, V. (2019). Effect of tray drying on the moisture kinetic and drying rate of osmo-dried papaya slices. South Asian Journal of Food Technology and Environment, 5(1): 791-796.

\section{Introduction}

The drying of fruits permits longer storage periods, reduces shipping weights, and minimizes their packaging requirements (Yeomans and Yang, 2014). Drying is a technique of conservation that consists of the elimination of large amount of water present in a food by the application of heat under controlled conditions, with the objective to diminish the chemical, enzymatic and microbiological activities that are responsible for the deterioration of foods (Barnabas et al., 2010). The mechanism of drying process consist of the transport of (mass) moisture from the interior of the solid to the surface, the vaporization of liquid at the surface (diffusion) and the transport of the vapor into gas phase (Seyed et al., 1999). The drying operation reduces the moisture content of solids to a condition favorable for safe storage without deteriorations. The most significance reason for the popularity of dried products is that in dehydrated foods, microorganisms practically do not grow due to the presence of a minimum amount of water and thus they are immune to enzymatic reactions that could spoilage in the food (Agarry and Owabor 2012; Hatamipour et al., 2007 and Gumus and Ketebe, 2013). This helps to shorten the dehydration time and control undesirable biological transformations. The objective of this study was calculation of moisture content and drying rate during drying process. Drying is a simultaneous heat and mass transfer process, where heat is supplied to wet papaya by heated air and the evaporated moisture is carried away by the air (Akhtaruzzaman et al., 2013). The drying rate is a function of product moisture content. In the drying rate period the most surface of product behaves like a free water surface. This period continues till the rate of evaporation of water from the surface is equal to the rate of moisture migration from interior of product to its surface. The constant drying period continues till critical moisture content is 
Vikrant Kumar, Jaivir Singh, Suresh Chandra, Neelash Chauhan, Ratnesh Kumar, Sunil and Vipul Chaudhary

reached. The critical moisture content is dependent on product and its thickness (Sahay and Singh 1994).

\section{Materials and Methods}

Experimental Plan: Papaya slices were pretreatment with treatments $\left(\mathrm{T}_{1}=\right.$ Potassium Metabisulphate, $\mathrm{T}_{2}=$ Sodium bisulphate and $\mathrm{T}_{3}$ $=$ Blanching at $95^{\circ} \mathrm{C}$ for $4 \mathrm{~min}$.) in osmotic solution at temperature of $50^{\circ} \mathrm{C}$. Then the samples were dried under tray drier at $60^{\circ} \mathrm{C}$ temperature. During the process, osmosis was carried out in sucrose solution at a varying concentration of $55^{\circ}$ Brix and $65^{\circ}$ Brix. At each experimental condition, osmotic dehydration was carried out for 180 minutes and data are observed at each 30 min intervals.

Experimental procedure: The papaya was procured from the local market of Meerut (UP) in 2018. The papaya was then washed, and decides into $2.5 \times 2.5 \times 2.5 \mathrm{~cm}$ Size. The papaya slices were treated above decided treatments for 30 minutes and then the sample were removed from treated solution and placed at room temperature for 15 minutes and then weighted by electrical balance. After that the samples were osmosed with sugar solution $\left(55^{\circ} \mathrm{Brix}\right.$ and $65{ }^{\circ}$ Brix) for 180 minutes at $50{ }^{\circ} \mathrm{C}$ temperature and then the osmotically papaya slices were dried in tray drying at $60{ }^{\circ} \mathrm{C}$.

Moisture content: Moisture content of the sample was determined by standard air oven method (Rangana, 2001). Test sample of $5 \mathrm{~g}$ was kept for 16-18 $\mathrm{hr}$ in a hot air electric oven maintained at $100^{\circ} \mathrm{C}$. After $16-18 \mathrm{hr}$, sample was drawn from the oven and placed in a desiccator for cooling. After cooling the weight of the sample was taken precisely. The loss in weight was determined and moisture content was calculated using the following expression:

Where,

$$
\begin{gathered}
\text { M C } \%(w b)=\frac{M 1-M 2}{M 0} \times 100 \\
\text { M C } \%(d b)=\frac{M \cdot C \cdot(w b)}{1-M . C .(w b)} \times 100
\end{gathered}
$$

$\mathrm{M}_{0}=$ Initial weight of sample taken, $5 \mathrm{~g}$

$\mathrm{M}_{1}=$ Weight of sample before tray

drying and weight of dish with cover, $\mathrm{g}$

$\mathrm{M}_{2}=$ Weight of the dish with cover

containing dried and desiccated sample, $\mathrm{g}$
Drying Rate: Drying rate will be calculated as weight of water removed per unit time per unit weight of the bone dry matter.

Drying rate (\%)

$=\frac{\text { Weight of water removed }(\mathrm{g})}{\text { time }(\text { min. }) \times \text { bone dry weight of the sample }(\mathrm{g})}$

\section{Results and Discussion}

\section{Effect on moisture content}

Fresh Papaya of good and uniform quality was obtained from a local market (Modipuram). The average initial moisture content was $89 \%(\mathrm{wb})$ and soluble solids content was $15^{\circ}$ Brix. The effects on moisture content during drying of osmosed dried papaya slices under tray dryer at $60^{\circ} \mathrm{C}$. The result presented in Table 1 and Fig. $1 \& 2$. Moisture content followed a slight decreasing trend as the drying period increases. The variations in moisture content of osmosed dried papaya slices with time were ranged from 236.2 to $2.4\left(\mathrm{~T}_{1}\right), 254.1$ to $5.3\left(\mathrm{~T}_{2}\right)$ and 166.9 to $1.7\left(\mathrm{~T}_{3}\right)$ of $55^{\circ} \mathrm{Brix}$ from 0 to 540 minutes, while the variations of moisture content were ranged from 205.33 to $3.66\left(\mathrm{~T}_{1}\right), 259.72$ to $3.12\left(\mathrm{~T}_{2}\right)$ and 198.72 to 5.9 $\left(\mathrm{T}_{3}\right)$ of $65{ }^{\circ}$ Brix from 0 to 540 minutes. The moisture content decreased as time increases but tend to be constant with further increase in time. The loss in water content of a sample is depending on drying time. In general the time of treatment increase, the weight loss increased but the rate at which this occur decrease (Kumari et al., 2013).

\section{Effect on drying rate}

The drying behavior of osmodehydrated papaya slices was analyzed using the experimental data of moisture of product. Time interval varies from 0 to 540 minutes at $60^{\circ} \mathrm{C}$ temperature. The experimental data of the drying behavior of dried papaya slices with relation to moisture content, and drying rate are show in table 2 and figure 3 to 4 . It was observed from the curves that the drying rate was higher in the initial period of drying and subsequently it was reduced with decrease in moisture content. The drying in falling rate period indicates that internal mass transfer occurred by diffusion. 
Similar results have been reported for the drying studies on onion slices (Rapusas and Driscoll, 1995) and apricots (Doymaz, 2004). The variations in drying rate of osmosed dried papaya slices with time were ranged from 0.699 to $0.0061\left(\mathrm{~T}_{1}\right), 0.52$ to $0.0041\left(\mathrm{~T}_{2}\right)$ and 0.75 to $0.0073\left(\mathrm{~T}_{3}\right)$ of $55{ }^{\circ}$ Brix from 60 to 540 minutes, while the variations of drying rate were ranged from 1.003 to $0.006\left(\mathrm{~T}_{1}\right), 1.379$ to $0.013\left(\mathrm{~T}_{2}\right)$ and 0.776 to $0.015\left(\mathrm{~T}_{3}\right)$ of $65^{\circ} \mathrm{Brix}$ from 60 to 540 minutes. The drying rate cure decreased as time increases but tend to be constant with further increase in time. The higher drying rate at the start of drying is due to high surface moisture availability, which evaporates rapidly. Further decrease in drying rate is owed to decrease in available moisture due to low driving force and low moisture diffusion from center to surface of the dried product. Similar results were found by (Rocha et al., 1992). Drying time provides an indication of drying rate. Drying rate of the samples was high initially when the moisture content was highest (Kumari, et al., 2013). The entire osmotic as well tray drying took place in falling rate period. The final moisture content of samples basically depends upon initial moisture content of the samples, if all conditions are steady.

Table 1: Effect of treatments and tray drying $\left(60^{\circ} \mathrm{C}\right)$ on moisture content $(\%)$ of osmosed dried papaya slices.

\begin{tabular}{|c|c|c|c|c|c|c|}
\hline \multirow{2}{*}{ Time (min.) } & \multicolumn{2}{|c|}{$\mathbf{T}_{\mathbf{1}}$} & \multicolumn{2}{|c|}{$\mathbf{T}_{\mathbf{2}}$} & \multicolumn{2}{c|}{$\mathbf{T}_{\mathbf{3}}$} \\
\cline { 2 - 7 } & $\mathbf{5 5}^{\mathbf{}}$ Brix & $\mathbf{6 5}^{\mathbf{0}}$ Brix & $\mathbf{5 5}^{\mathbf{B}}$ Brix & $\mathbf{6 5}^{\mathbf{}}$ Brix & $\mathbf{5 5}^{\mathbf{0}}$ Brix & $\mathbf{6 5}^{\mathbf{0}}$ Brix \\
\hline 0 & 236.2 & 205.336 & 254.1 & 259.721 & 166.9 & 198.724 \\
60 & 194.8 & 145.147 & 228.9 & 177.008 & 121.9 & 152.367 \\
120 & 11.6 & 106.171 & 158.0 & 129.017 & 99.0 & 117.293 \\
180 & 83.8 & 83.3907 & 120.5 & 101.525 & 75.0 & 96.3254 \\
240 & 41.9 & 45.2591 & 78.5 & 56.7572 & 36.9 & 62.4065 \\
300 & 28.5 & 33.1735 & 47.2 & 44.6625 & 27.9 & 54.2215 \\
360 & 20.5 & 26.7732 & 33.4 & 29.1923 & 19.0 & 35.5011 \\
420 & 9.7 & 13.0676 & 12.2 & 18.2058 & 9.3 & 24.5575 \\
480 & 5.7 & 6.87411 & 7.5 & 10.3633 & 5.7 & 14.1486 \\
540 & 2.4 & 3.66656 & 5.3 & 3.12345 & 1.7 & 5.96059 \\
\hline
\end{tabular}

Description: $\left(\mathrm{T}_{1}=\right.$ Potassium Metabisulphate, $\mathrm{T}_{2}=$ Sodium bisulphate and $\mathrm{T}_{3}=$ Blanching $)$

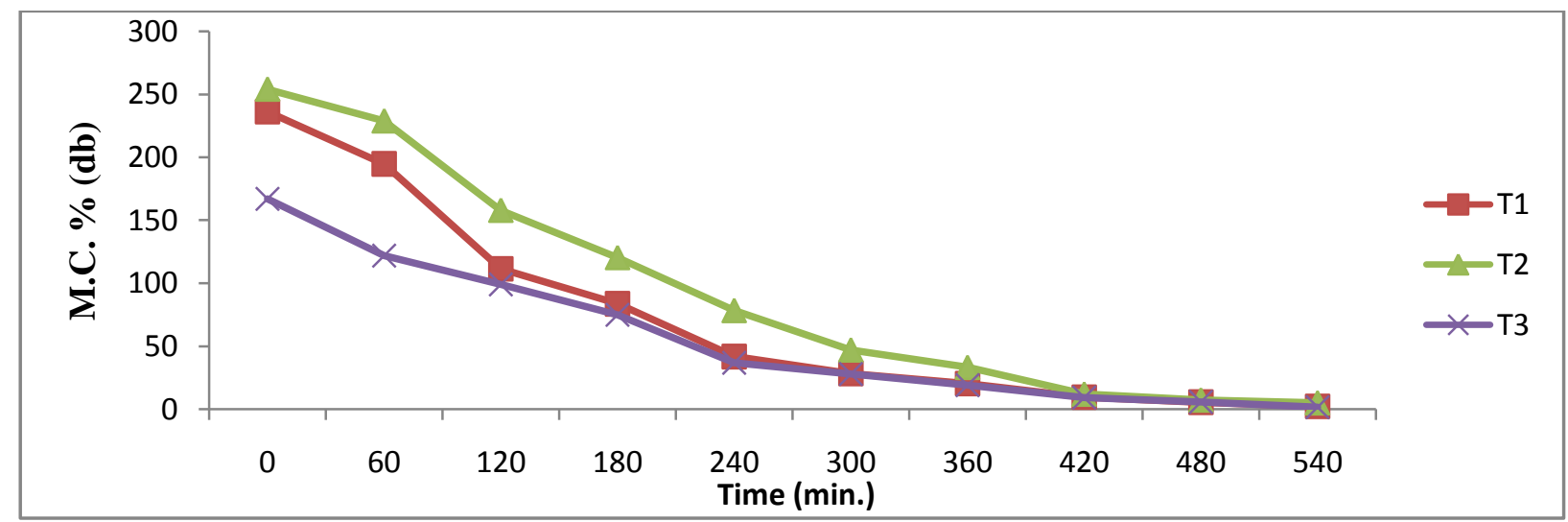

Fig. 1: Effect of treatments and tray drying $\left(60^{\circ} \mathrm{C}\right)$ on moisture content $(\%)$ of osmosed $\left(55^{\circ} \mathrm{Brix}\right)$ dried papaya slices. 


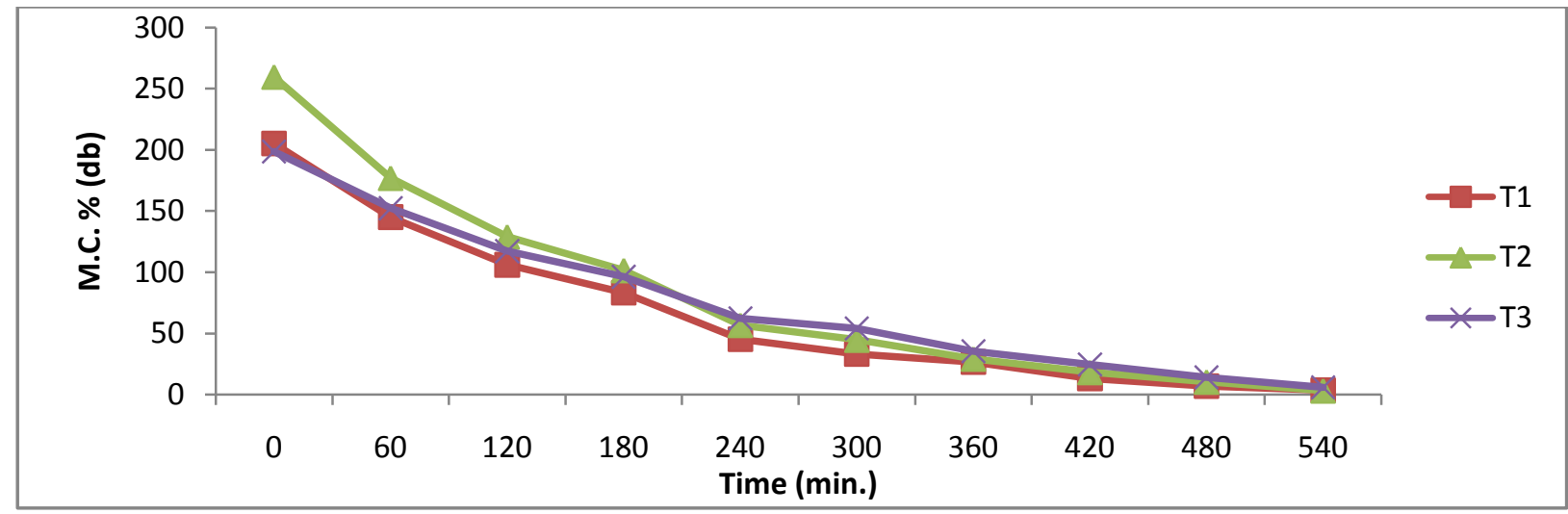

Fig. 2: Effect of treatments and tray drying $\left(60^{\circ} \mathrm{C}\right)$ on moisture content $(\%)$ of osmosed $\left(65^{\circ} \mathrm{Brix}\right)$ dried papaya slices.

Table 2: Effect of treatments and tray drying $\left(60^{\circ} \mathrm{C}\right)$ on drying rate of osmosed dried papaya slices.

\begin{tabular}{|c|c|c|c|c|c|c|}
\hline \multirow{2}{*}{$\begin{array}{c}\text { Time } \\
\text { (min.) }\end{array}$} & \multicolumn{2}{|c|}{$\mathbf{T}_{\mathbf{1}}$} & \multicolumn{2}{c|}{$\mathbf{T}_{\mathbf{2}}$} & \multicolumn{2}{c|}{$\mathbf{T}_{\mathbf{3}}$} \\
\cline { 2 - 7 } & $\mathbf{5 5}^{\mathbf{B}}$ Brix & $\mathbf{6 5}^{\mathbf{}}$ Brix & $\mathbf{5 5}^{\mathbf{}}$ Brix & $\mathbf{6 5}^{\mathbf{0}}$ Brix & $\mathbf{5 5}^{\mathbf{0}}$ Brix & $\mathbf{6 5}^{\mathbf{0}}$ Brix \\
\hline 60 & 0.69912 & 1.00315 & 0.52114 & 1.379 & 0.74889 & 0.77261 \\
120 & 0.68385 & 0.32479 & 0.49052 & 0.39992 & 0.19061 & 0.29228 \\
180 & 0.17438 & 0.15656 & 0.20857 & 0.18273 & 0.15346 & 0.14649 \\
240 & 0.15412 & 0.14888 & 0.17482 & 0.15653 & 0.13903 & 0.11133 \\
300 & 0.04487 & 0.1029 & 0.10422 & 0.04232 & 0.03003 & 0.05728 \\
360 & 0.02518 & 0.03778 & 0.05837 & 0.04097 & 0.02457 & 0.02601 \\
420 & 0.02268 & 0.02263 & 0.03046 & 0.02616 & 0.02311 & 0.02206 \\
480 & 0.00836 & 0.0129 & 0.00985 & 0.01634 & 0.00753 & 0.02169 \\
540 & 0.00607 & 0.00594 & 0.00413 & 0.01341 & 0.00732 & 0.01516 \\
\hline
\end{tabular}

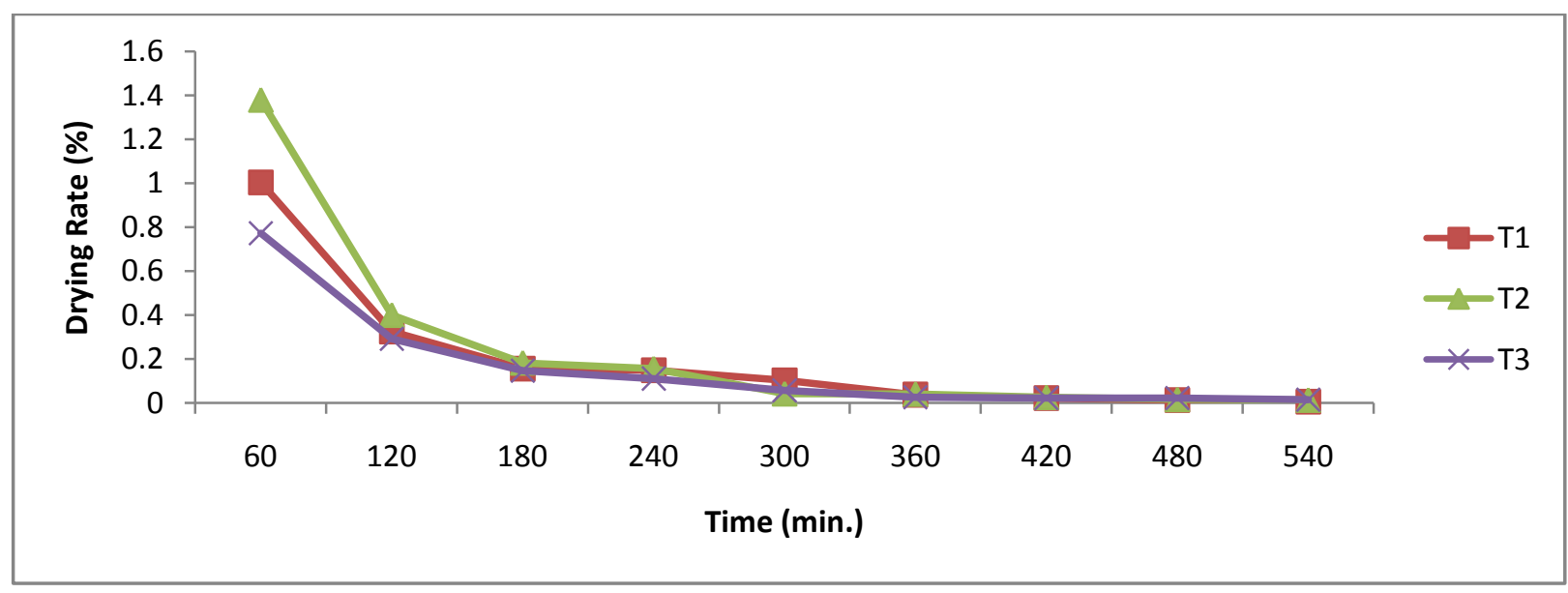

Fig. 3: Effect of treatments and tray drying $\left(60^{\circ} \mathrm{C}\right)$ on drying rate of osmosed $\left(55^{\circ} \mathrm{Brix}\right)$ dried papaya slices. 


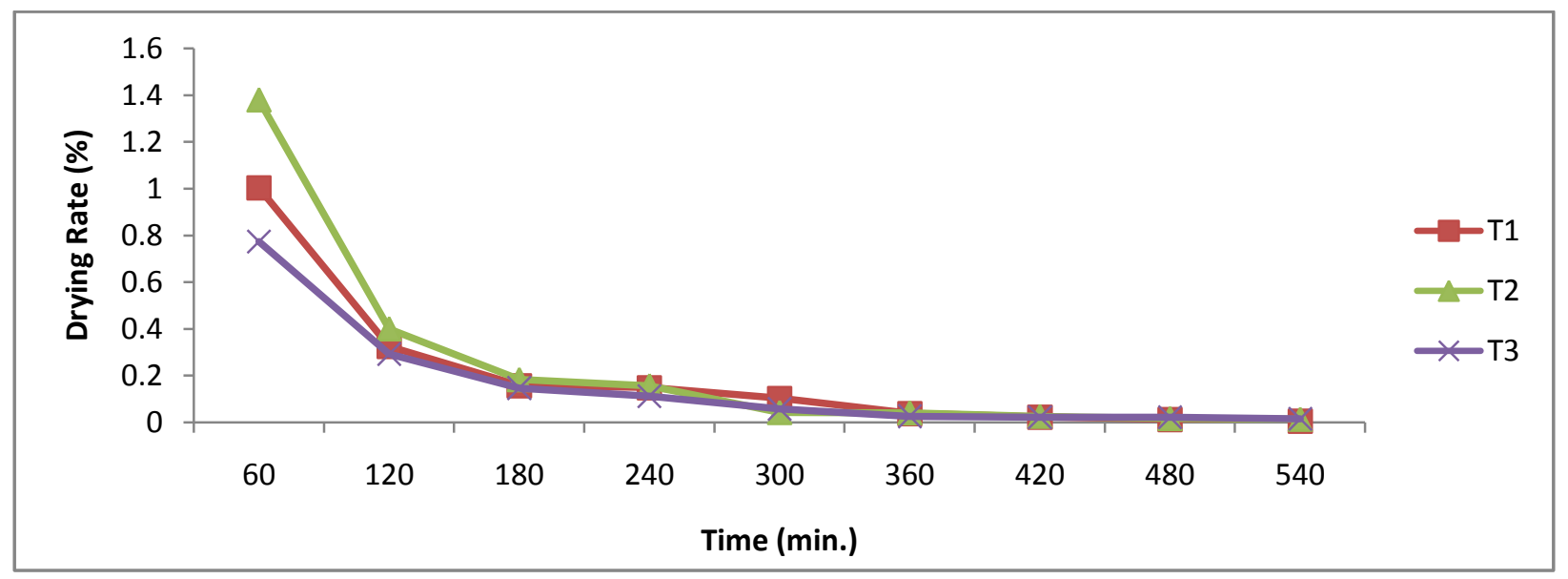

Fig. 4: Effect of treatments and tray drying $\left(60^{\circ} \mathrm{C}\right)$ on drying rate of osmosed $\left(65^{\circ} \mathrm{Brix}\right)$ dried papaya slices.

\section{Conclusion}

In this study, the kinetics drying of papaya slices were experimentally studied under $60^{\circ} \mathrm{C}$ temperature. The drying temperature has an essential role in the characterization of drying behavior of papaya samples. The increase in drying time consequently decreases the drying rate.

\section{Acknowledgements}

We would like to acknowledge the department of agricultural engineering (S.V.P. Uni. Agri. and Tech. Meerut, UP, India) for providing facilities to conduct the experiment.

\section{References}

Agarry, S.E. and Owabor, C.N. (2012). Modelling of the drying kinetics of Banana under natural convection and forced air drying. Journal of the Nigerian Society of Chemical Engineers, 27(1): 103-115.

Akhtaruzzaman, M., Ali. M.R., Rahman, M.M. and Ahamed, M.S. (2013). Drying tea in a kilburn vibro fluid bed dryer. Journal of Bangladesh Agricultural University, 11(1): 153-158.

Barnabas, M., Siores, E. and Lamb, A. (2010). Non-thermal microwave reduction of pathogenic cellular population.
International journal of Food Engineering, 6:1-18.

Doymaz, I. (2004). Effect of pre-treatment using potassium metabisulphite and alkaline ethyl oleate on the drying kinetics of apricots. Biosystems Engineering, 89:281-287.

Gumus, R.H. and Ketebe, E. (2013). The Effect of Temperature on Drying Rate of Agro Food: Corn (Maize) and Ogbono (Irivingia Gabonnensis). Journal of Engineering, 3(3): 36-42.

Hatamipour, M.S., hadji Kazemi, H., Nooralivand, A. and Nozarpoor (2007). Drying characteristics of six varities of sweet potatoes in different dryers. Trans Chemical Part C. Food and Bio-product processing, 85(3): 171-177.

Kumari, D., Chandra, S. and Samsher (2013). Assessment of mass transfer properties during osmotic dehydration of ripe banana slice. Beverage and food world, 40(12): 39-42.

Ranganna, S. (2001). Hand book of Analysis and quality control of fruit and vegetable products. Tata McGraw Hill Pub. Co. Ltd. New Delhi

Rapusas, R.S. and Drisoll R.H. (1995). Thermo physical properties of fresh and dried whileonion slices. Journal of Food Engineering, 24: 955-963.

Rocha, T., Lebert, A. and Marty-Audoin, C. (1992). Effect of drying condition on 
Vikrant Kumar, Jaivir Singh, Suresh Chandra, Neelash Chauhan, Ratnesh Kumar, Sunil and Vipul Chaudhary

color of mint and basil (oumun basilium). A.S. Muyumber (Ed), pp. 1360-66.

Sahay, K.M. and Singh, K.K. (2001). Unit operations of agricultural processing. Vikas publishing house Pvt. Ltd., New Delhi. $2^{\text {nd }}$ Ed. Pp. 126.

Seyed, J.Y., Moreira, R.G. and Yamseangsung, R. (1999). Superheated steam impingement drying of tortilla chip. Drying Technology, 17:191-213.

Yeomans, S.J. and Yang, S.X. (2014). Determining optimal osmotic drying parameters for papaya using the firefly algorithm. Lecture Notes in Management Science, 6: 32-39.

$\begin{array}{ll}\text { Received } & \text { : March, } 2019 \\ \text { Revised } & \text { : April, 2019 } \\ \text { Published } & \text { : June, 2019 }\end{array}$

